\title{
Haemophiliacs to sue
}

\section{Tokyo}

A SMALL but growing number of Japanese haemophiliacs suffering from AIDS are planning to sue the Japanese government and pharmaceutical companies for their role in the import of the US blood products that are believed to be the prime source of AIDS infection in Japan.

At the end of last month, seven haemophiliacs filed suit in an Osaka district court claiming $¥ 805$ million (about $\$ 6$ million) in damages from the state and five pharmaceutical companies - Green Cross Corporation, Baxter Travenol, Bayer Yakuhin, Nippon Zoki Pharmaceuticals and the Chemo-Sero-Therapeutic Research Institute. The suit, which claims that the government and companies failed to check the safety of imported blood products, is very similar to one filed by two haemophiliacs in May.

The number of AIDS cases in Japan is still small compared with Western nations but more than half of the approximately 100 AIDS patients and more than 90 per cent of the 1,000 or so identified carriers of the AIDS virus are haemophiliacs. They were infected by non-heat-treated blood products imported from the United States between 1979 and 1985 (when heattreated products were allowed on the market in Japan). Earlier this year, the government and pharmaceutical companies established a fund of several million dollars to compensate haemophiliac AIDS sufferers and their families but did not admit any responsibility for AIDS infection.

Critical to a resolution of the court case will be a determination of exactly when it became clear that non-heat-treated blood coagulants are a potential source of AIDS infection. Japanese haemophiliacs first called on the Ministry of Health and Welfare to introduce heat-treated coagulants in 1983. But government approval of heat-treated products did not come until two years later and Japan continued to import non-heat-treated blood products from the United States after their use was banned in the United States and other Western nations.

Ministry officials and some of their academic advisers argue that it was not clear in 1983 that untreated blood coagulants are a source of AIDS infection. They say they cut corners to approve heattreated products quickly. But some representatives of haemophiliacs claim that approval was unnecessarily delayed.

Japanese haemophiliacs suffering from AIDS have hesitated to take legal action through fear of public exposure. But in May, Fumio Akase, a 52-year-old calligrapher, and another haemophiliac, who remains anonymous, filed suit against Green Cross, Baxter Trevanol and the government claiming $¥ 230$ million in damages. Akase says he decided to reveal his name in the hope that it would draw attention to the plight of the approximately 2,000 Japanese haemophiliacs thought to carry the AIDS virus.

Akase's decision to reveal his name has NUCLEAR WASTE

\section{Billion dollar clean-up plan announced}

\section{Boston}

THE US Department of Energy last week announced a five-year, \$19,600-million environmental clean-up plan for its contaminated nuclear-weapons production facilities. The plan is the culmination of a highly visible effort in the department over the past four months to come to grips with its environmental problems, and of numerous pledges from Energy Secretary James D. Watkins that the issue would receive higher priority.

While the details will not be available publicly until the end of this month, the plan commits the department to restoring its sites to compliance with federal environmental laws within the next 30 years. Among the department's promises are the release of the health records of workers at weapons facilities and the implementation of programmes to minimize waste generation.

Watkins says he hopes that the plan will restore public confidence in the department's ability to manage and operate its facilities safely, furthering what he called its "proper role as a protector of the environment".

The proposed plan commits a huge sum of federal money to the clean-up task, considerably greater even than the Energy Department's own \$14,000-million annual budget. But this may still not be sufficient. Overall estimates of the Energy Department's total clean-up bill run as high as $\$ 200,000$ million.

Senator John Glenn, a critic of the department's past "scattered and piecemeal" clean-up efforts, says the Energy Department is now "moving in the right direction". He plans to call on the General Accounting Office to assess the plan once it is released in full. Environmental groups have also welcomed the plan.

But James Beard, director of the Nuclear Weapons Project at the Environmental Policy Institute in Washington, is more critical, expressing concern that the programme is trying to do too much with too little money. According to Beard, twice as much money should be budgeted annually to address the problem fully.

Seth Shulman caused him problems. In a court hearing on 28 July he complained bitterly that the hospital he was attending has refused further treatment. But his action is said to have encouraged the new group to file suit. Further suits are expected but the plaintiffs may not live to hear the final decision. In Japan, such court cases have often taken ten or twenty years to resolve.

David Swinbanks

\section{CHINA \\ Another attack on Fang Lizhi}

\section{London}

DR Fang Lizhi, the Chinese astrophysicist and campaigner for democracy, who took refuge in the US Embassy in Beijing following the military intervention in Tiananmen Square, has been formally dismissed from his post with China's Committee for Academic Degrees, the Chinese news agency, Xinhua, reported on 4 August.

Fang, who had been a member of the committee's "astronomy appraisal group" was dismissed, the agency said, because he was subject to an arrest warrant approved by the public prosecutor.

This is the latest in a series of attacks and ritual humiliations for Fang, who, in Chinese official eyes, is guilty of treachery by the very fact of fleeing to the embassy. Last month, he was removed from the posts he held in the Chinese Natural Dialectics Research Society. His past statements are quoted by the Chinese media out of context. Thus his remark last April that, if the authorities did not enter into dialogue with the protesting students, there would be an increase in tension is now quoted as an incitement to rebellion rather than an informed prediction.

The charge sheet against him includes "counter-revolutionary propaganda and instigation", and he was even accused two weeks ago in the Beijing Daily of advocating "the extinction of the Chinese race". Indeed, in the eyes of the Chinese authorities, Fang's guilt is so accepted that contact with him is now regularly cited as evidence of guilt in others. So, in an attack on the 'Federation of Autonomous Students Unions' which organized the sit-in at Tiananmen Square, the daily newspaper Renmin Ribao claimed that for more than a year some of its leading members had organized weekly seminars at which "leading associates of bourgeois liberalization, such as Professor Fang Lizhi" had been asked to speak. And in recording the dismissal of another "bourgeois liberal", Wen Yuankai from the Anhui Provincial Education Commission, Xinhua stressed that Wen is a professor at the Chinese University of Science and Technology, the university of which Fang was vice president until January 1987.

Vera Rich 